\title{
Pengaruh Aplikasi Bahan Pemutih Gigi Karbamid Peroksida $10 \%$ dan Hidrogen Peroksida 6\% secara Home Bleaching terhadap Kekerasan Permukaan Email Gigi
}

\author{
Meiyestri Dwi Riani ${ }^{1}$, Fadil Oenzil ${ }^{2}$, Nila Kasuma ${ }^{3}$
}

\begin{abstract}
Abstrak
Home bleaching adalah teknik pemutihan gigi vital yang dilakukan oleh pasien di rumah dalam pengawasan dokter gigi dengan konsentrasi karbamid peroksida $10-16 \%$ atau 3-6\% hidrogen peroksida. Tujuan penelitian ini adalah untuk mengetahui pengaruh aplikasi bahan pemutih gigi karbamid peroksida $10 \%$ dan hidrogen peroksida $6 \%$ secara home bleaching terhadap kekerasan permukaan email gigi. Metode penelitian adalah true experimental dengan pretest-posttest control group design. Sampel berupa gigi premolar satu rahang atas yang sudah diekstraksi sebanyak 32 buah yang dibagi menjadi dua kelompok. Kelompok 1 adalah kelompok aplikasi bahan pemutih gigi karbamid peroksida 10\% dengan lama aplikasi 1 jam perhari selama 14 hari dan kelompok II adalah kelompok aplikasi bahan pemutih gigi hidrogen peroksida $6 \%$ dengan lama aplikasi 10 menit perhari selama 14 hari. Selama aplikasi kedua sampel berada dalam inkubator $37^{\circ} \mathrm{C}$. Kekerasan permukaan email gigi diukur dengan alat Vickers Harndness Tester. Analisis data yang digunakan adalah uji $t$ independen dan uji t dependen $(\mathrm{p}<0,05)$. Hasil uji statistik menunjukkan terjadinya penurunan yang sangat signifikan $0,000(p<0,05)$ pada rerata nilai kekerasan permukaan email gigi antara sebelum dan setelah aplikasi bahan pemuth gigi. Kedua bahan pemutih gigi ini mempunyai perbandingan yang cenderung tidak signifikan $0,073(p>0,05)$ terhadap kekerasan permukaan email gigi setelah aplikasi bahan pemutih gigi. Disimpulkan bahwa bahan pemutih gigi dapat menyebabkan penurunan kekerasan permukaan email gigi yang sangat signifikan karena terjadinya demineralisasi.
\end{abstract}

Kata kunci: karbamid peroksida, hydrogen peroksida, home bleaching, kekerasan permukaan email gigi

\section{Abstract}

Home bleaching is whitening treatment of vital teeth conducted by a patient at home with under control of a dentist. The consentration of bleaching agents are $10-16 \%$ of carbamid peroxide or $3-6 \%$ of hidrogen peroxide. The objective of this study was to investigate the effect of application bleaching agents $10 \%$ of carbamide peroxide and $6 \%$ of hidrogen peroxide in home bleaching on enamel hardness surface. The method that used in this study is using true experimental with pre test-post test contol group design. Sample of the study using first premolar maxillary had been extracted into 32 pieces that divided into two treatments groups. Group I was applied by $10 \%$ of carbamide peroxide for 1 hours a day and group II was applied by $6 \%$ of hidrogen peroxide for 10 minutes a day and the duration of application was 14 days. Both of the groups were in the incubator $37^{\circ} \mathrm{C}$. Enamel hardness surface was measure by Vickers Hardness Tester. This study used independent $t$-test and paired sample $t$-test $(p<0.05)$. The result of this study showed that significant decrasing $0.000(p<0.05)$ of enamel hardness surface in average between before and after applied. Both of bleaching agents have the comparison that tend to be not significantly 0.073 ( $p>0.05)$ on enamel hardness surface after application of bleaching agents with significant value were. The conclusion is bleaching agents can affect enamel by decreasing enamel hardness surface value which are marked significant because demineralizion. Keywords:carbamide peroxide, hidrogen peroxide, home bleaching, enamel hardness surface 
Affiliasi penulis1. Pendidikan dokter Gigi FKG UNAND (Fakultas Kedokteran Gigi Universitas Andalas Padang, 2. Bagian Biokimia FK UNAND, 3. FKG UNAND

Korespondensi : Meiyestri Dwi Riani, E-mail:

meiyestridwi_riani@yahoo.co.id Telp: 08116681051

\section{PENDAHULUAN}

Gigi merupakan salah satu faktor estetika penting bagi pasien, termasuk warna gigi. Di Inggris telah dilaporkan bahwa $28 \%$ orang dewasa tidak puas dengan penampilan warna giginya dan di Amerika Serikat, $34 \%$ populasi orang dewasa tidak puas dengan warna gigi aslinya. Adanya diskolorasi (perubahan warna gigi) ekstrinsik dan intrinsik yang dapat terjadi pada gigi vital atau non vital akan mempengaruhi estetika dan kepribadian seseorang. Salah satu perawatan konservatif yang dapat digunakan dalam mengatasi permasalahan warna gigi adalah dengan melakukan pemutihan gigi (bleaching) ${ }^{1-4}$

Bleaching merupakan suatu prosedur pemutihan kembali gigi yang merubah warna sampai mendekati warna asli gigi dengan proses perbaikan secara kimiawi yang bertujuan untuk mengembalikan estetika gigi seseorang. ${ }^{5,6}$ Bleaching sudah mulai populer sejak abad 19. ${ }^{7}$ Prosedur bleaching dapat dilakukan secara in office bleaching (dikerjakan di klinik oleh dokter gigi secara langsung) atau home bleaching (dilakukan di rumah dengan pantauan dokter gigi), dan dapat dilakukan secara internal untuk gigi non vital maupun eksternal untuk gigi vital. ${ }^{6-9}$

Sejak diperkenalkannya sistem home bleaching oleh Haywood dan Heymann pada tahun 1989 kepada masyarakat, penggunaan bleaching makin meluas. Keuntungan dari sistem ini adalah aplikasinya yang relatif mudah yaitu dengan menggunakan sendok cetak khusus (tray), biaya yang lebih terjangkau, secara umum dapat diterima oleh pasien dari semua kelas sosial-ekonomi, lebih aman untuk digunakan dan persentase kesuksesan yang tinggi. ${ }^{10}$

Kandungan bahan kimia yang sering digunakan sebagai pemuth gigi adalah karbamid peroksida dan hidrogen peroksida. Karbamid peroksida dan hidrogen peroksida terutama diindikasikan untuk pemutihan gigi eksternal. ${ }^{6}$ Kedua bahan ini mengandung bahan yang sama, yaitu hidrogen peroksida yang akan terurai menjadi $\mathrm{H}_{2} \mathrm{O}$ dan $\mathrm{O}_{2} .{ }^{7}$ Konsentrasi hidrogen peroksida yang digunakan pada pemutihan gigi bervariasi. Semakin tinggi konsentrasi hidrogen peroksida yang dipakai maka akan semakin terang warna gigi yang dihasilkan. Salah satu sistem pemutihan gigi yang menggunakan konsentrasi hidrogen peroksida yang tinggi $(30-38 \%)$ adalah power bleaching atau in office bleaching. ${ }^{1}$

Karbamid peroksida dengan konsentrasi $10 \%$ (mengandung 3,6\% hidrogen peroksida dan 6,4\% urea) umum digunakan pada prosedur home bleaching, konsentrasi ini telah disetujui sebagai bahan yang aman dan efektif oleh American Dental Association (ADA) untuk penggunaan di luar klinik gigi. Efektivitas proses pemutihan gigi karbamid peroksida sebagai bahan home bleaching belum ada penggantinya, namun penggunaannya sampai saat ini masih terus diperdebatkan karena terdapat efek yang ditimbulkan terhadap rongga mulut seperti iritasi gingiva dan gigi sensitif. ${ }^{5,8}$

Perdigao et al melakukan penelitian di tahun 1988, mengenai efek karbamid peroksida 10\% terhadap email dan hasilnya dapat menurunkan jumlah kalsium, fosfat, dan fluoride pada email, dan akibatnya terjadi perubahan microhardness email. Bebeda dengan penemuan Crew et al yang menggambarkan peningkatan jumlah kalsium dan fosfat pada email yang dilakukan pemutihan dengan karbamid peroksida. Hal ini didukung bahwa defek mikrostruktural dapat diperbaiki oleh absorbsi atau pengendapan komponen saliva, seperti kalsium dan fosfat. Perubahan kekerasan email setelah diputihkan dengan karbamid peroksida tergantung pada produk yang digunakan dan tingkat keasamannya. ${ }^{7}$

Penelitian secara in vitro yang menguji bahan pemutih gigi hidrogen peroksida $6 \%$ terhadap email menyatakan bahwa, pengikisan email akibat penggunaan bahan tersebut masih dapat diterima. ${ }^{11}$ Pada penelitian lain telah dilaporkan bahwa tidak ada perubahan kekerasan dan kekasaran email gigi yang bermakna setelah pemutihan dengan hidrogen peroksida. Beberapa penelitian lainnya menyatakan bahwa konsentrasi hidrogen peroksida yang tinggi dapat menyebabkan penurunan kekerasan permukaan email gigi secara bermakna karena terjadi 
demineralisasi. ${ }^{1}$

Kekerasan email merupakan salah satu sifat fisik email yang dipengaruhi oleh banyaknya jumlah bahan anorganik seperti kalsium. Larutnya sebagian kalsium dari kristal hidroksi apatit menyebabkan kekerasan email menjadi menurun sehingga rentan terhadap terjadinya karies. ${ }^{7}$ Kekerasan merupakan ketahanan suatu bahan dalam menahan indentasi. Kekerasan permukaan mikro juga merupakan faktor yang paling penting dalam karakteristik fisik suatu material gigi. Nilai suatu kekerasan biasanya dinyatakan dalam satuan VickersHardness Number $(V H N)$, tergantung metode yang digunakan. Kekerasan email gigi dapat diukur dengan menggunakan alat Vickers Hardness Tester atau Knoop Hardness Tester. ${ }^{12}$

Berdasarkan uraian di atas, maka dilakukanlah penelitian lebih lanjut mengenai pengaruh aplikasi bahan pemutih gigi karbamid peroksida $10 \%$ dan hidrogen peroksida $6 \%$ secara home bleaching terhadap kekerasan permukaan email gigi.

\section{METODE}

Penelitian ini merupakan penelitian true experimental, dengan rancangan penelitian pre testpost test control group design karena membandingkan keadaan sebelum dan setelah diberi perlakuan. Pada penelitian ini menggunakan 32 gigi premolar satu rahang atas pasca ekstraksi (telah dicabut) karena alasan orthodontik tanpa karies dan fraktur yang disimpan dalam aquabidest sampai saat digunakan dan menggunakan bahan bleaching karbamid peroksida $10 \%$ dan hidrogen peroksida $6 \%$.

Pada 32 sampel dilakukan pemotongan bagian cemento enamel junction untuk memisahkan mahkota dari akarnya. Sampel kemudian secara random dibagi menjadi dua kelompok yang masing-masing terdiri dari 16 buah sampel. Sampel kemudian ditanam dalam gips stone menggunakan mold silinder dengan bagian mesial menghadap ke atas. Tiap sampel pada tiap kelompok diberi nomor urut. Setelah penanaman selesai, dilakukan pengukuran awal kekerasan email gigi sebelum diberi perlakuan dengan menggunakan tiga titik indentasi pada 1/3 atas permukaan mesial gigi dengan menggunakan alat Vickers Hardness Tester. Selanjutnya sampel diberi perlakuan berupa aplikasi bahan pemutih gigi menggunakan kuas.

Setiap sampel pada kelompok I diaplikasikan karbamid peroksida 10\% pada permukaan mesial gigi, kemudian masukkan ke dalam inkubator dengan suhu $37^{\circ} \mathrm{C}$ selama 1 jam. Setelah 1 jam sampel dikeluarkan dari inkubator dan gigi dibersihkan dari sisa gel menggunakan sikat dibawah air mengalir. Kemudian sampel dimasukkan ke dalam wadah individual yang berisi aquabides dan disimpan kembali di dalam inkubator selama 23 jam. Hal ini dilakukan secara berulang selama 14 hari. Pada kelompok kedua, sampel diaplikasikan hidrogen peroksida $6 \%$ pada permukaan mesial gigi, kemudian masukkan kedalam inkubator dengan suhu $37^{\circ} \mathrm{C}$ selama 10 menit. Setelah 10 menit sampel dikeluarkan dari inkubator dan bersihkan gigi dari sisa gel menggunakan sikat dibawah air mengalir. Kemudian sampel dimasukkan ke dalam wadah individual yang berisi aquabides dan disimpan kembali di dalam inkubator selama 23 jam 50 menit dalam 14 hari.

Pada hari ke-14, sampel dikeluarkan dan tahap berikutnya dilakukan uji kekerasan permukaan email gigi dengan cara yang sama dengan uji kekerasan awal menggunakan alat Vickers Hardness Tester dengan tiga titik indentasi pada $1 / 3$ atas permukaan mesial gigi pada kedua kelompok sampel. Letak titik indentasi pada sampel ditempatkan berbeda dengan letak titik indentasi pada uji kekerasan awal. Data yang diperoleh kemudian ditabulasi, kemudian dilakukan analisis statistik menggunakan uji $\mathrm{t}$ independen (Independent $t$-test) dan uji $\mathrm{t}$ dependen (Paired Sample t-test) dengan tingkat kepercayaan 95\% $(p<0,05)$.

\section{HASIL}

Hasil uji kekerasan permukaan email gigi sebelum dan setelah aplikasi bahan pemutih gigi menggunakan alat Vickers Hardness Tester dapat dilihat pada Tabel 1. 
Tabel 1. Hasil pengukuran kekerasan permukaan email gigi sebelum aplikasi (pretest) dan setelah aplikasi (posttest) bahan pemutih gigi karbamid peroksida $10 \%$ dan hidrogen peroksida $6 \%$

\begin{tabular}{lccc}
\hline \multicolumn{1}{c}{ Variabel } & $\mathbf{n}$ & \multicolumn{2}{c}{$\begin{array}{c}\text { Rerata } \\
\text { (VHN) }\end{array}$} \\
\hline & & pretest & posttest \\
\cline { 3 - 4 } Karbamid Peroksida 10\% & 16 & 284,13 & 209,63 \\
Hidrogen Peroksida 6\% & 16 & 295,92 & 231,60 \\
\hline Keterangan: $\mathrm{n}=$ jumlah sampel & & &
\end{tabular}

Berdasarkan Tabel 1 dapat diketahui bahwa setelah aplikasi bahan pemutih gigi karbamid peroksida $10 \%$ dan hidrogen peroksida 6\% terjadi penurunan nilai rerata kekerasan permukaan email gigi.

Sebelum melakukan analisis data pada penelitian ini, maka terlebih dahulu dilakukan uji normalitas pada masing-masing kelompok sampel dengan menggunakan uji statistik Shapiro-Wilk untuk mengetahui apakah data penelitian ini terdistribusi normal atau tidak. Berdasarkan hasil uji normalitas Shapiro-Wilk pada variabel penelitian didapatkan bahwa data pada kedua kelompok perlakuan terdistribusi normal $(p>0,05)$, maka uji $t$-test dapat dilakukan.

Tabel 2. Perubahan nilai kekerasan permukaan email gigi sebelum dan setelah aplikasi bahan pemutih gigi karbamid peroksida $10 \%$

\begin{tabular}{lccc}
\hline Variabel & $\mathbf{n}$ & $\begin{array}{c}\text { Rerata } \pm \text { SD } \\
(\text { VHN) }\end{array}$ & p \\
& & $0,0001^{*}$ \\
Pretest & 16 & $284,13 \pm 32,46$ & \\
Postest & 16 & $209,63 \pm 30,20$ & \\
\hline
\end{tabular}

*signifikan $\mathrm{p}<0,05$

Berdasarkan Tabel 2 dapat dilihat bahwa nilai mean perbedaan kekerasan permukaan email gigi sebelum dan setelah aplikasi bahan pemutih gigi karbamid peroksida $10 \%$ adalah $74,50 \pm 31,14 \mathrm{VHN}$. Hasil uji statistik didapatkan nilai $p<0,05$ maka dapat disimpulkan bahawa terjadi penurunan yang sangat signifikan antara rerata nilai kekerasan permukaan email gigi sebelum dan setelah aplikasi bahan pemutih gigi karbamid peroksida $10 \%$.

Tabel 3. Perubahan nilai kekerasan permukaan email gigi sebelum dan setelah aplikasi bahan pemutih gigi hidrogen peroksida $6 \%$

\begin{tabular}{lccc}
\hline Variabel & $\mathbf{n}$ & $\begin{array}{c}\text { Rerata } \pm \text { SD } \\
(\text { VHN) }\end{array}$ & p \\
\hline Pretest & 16 & $296,06 \pm 29,82$ & $0,0001^{*}$ \\
Postest & 16 & $231,69 \pm 30,67$ & \\
& & & \\
\end{tabular}

*signifikan $\mathrm{p}<0.05$

Berdasarkan Tabel 3 dapat dilihat bahwa nilai rerata perbedaan kekerasan permukaan email gigi sebelum dan setelah aplikasi bahan pemutih gigi hidrogen peroksida $6 \%$ adalah $64,37 \pm 45,70$ VHN. Hasil uji statistik didapatkan $p<0,05$ maka dapat disimpulkan bahwa terjadi penurunan yang sangat signifikan antara rerata nilai kekerasan permukaan email gigi sebelum dan setelah aplikasi bahan pemutih gigi hidrogen peroksida 6\%.

Perubahan kekerasan permukaan email sebelum dan setelah aplikasi bahan pemutih gigi karbamid peroksida $10 \%$ dan hydrogen peroksida $6 \%$ dapat dilihat pada Gambar 1.

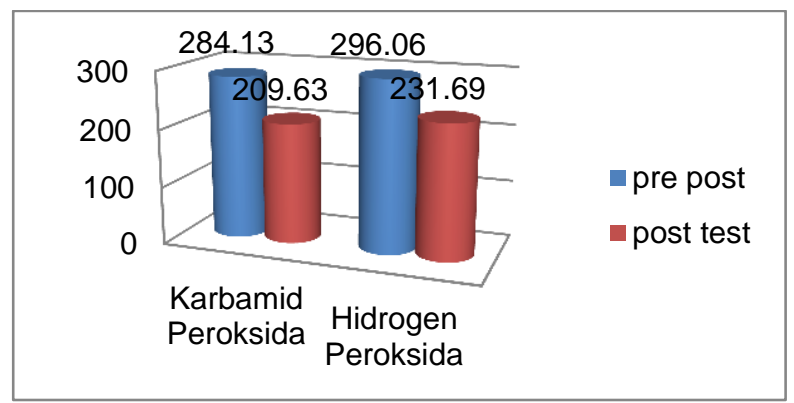

Gambar 1. Perubahan kekerasan permukaan email gigi sebelum dan setelah apikasi bahan pemutih gigi

Berdasarkan Tabel 4 dapat dilihat bahwa rerata nilai kekerasan permukaan email gigi setelah aplikasi bahan pemutih gigi karbamid peroksida $10 \%$ adalah $209,63 \pm 30,20$ VHN, sedangkan rerata nilai kekerasan permukaan email gigi setelah aplikasi bahan pemutih 
gigi hidrogen peroksida $6 \%$ adalah $231,69 \pm 30,67$ VHN.

Tabel 4. Perbandingan kedua jenis bahan pemutih gigi yang paling berpengaruh terhadap penurunan nilai kekerasan permukaan email gigi setelah diberi perlakuan berupa aplikasi bahan pemutih gigi karbamid peroksida $10 \%$ dan bahan pemutih gigi hidrogen peroksida $6 \%$

\begin{tabular}{lccc}
\hline \multicolumn{1}{c}{ Variabel } & $\mathbf{n}$ & $\begin{array}{c}\text { Rerata } \pm \text { SD } \\
\text { (VHN) }\end{array}$ & $\mathbf{p}$ \\
\hline Karbamid & 16 & $209,63 \pm 30,20$ & 0,073 \\
$\begin{array}{l}\text { Peroksida } 10 \% \\
\text { Hidrogen }\end{array}$ & 16 & $231,69 \pm 30,67$ & 0,073 \\
Peroksida 6\% & & & \\
\hline
\end{tabular}

Hasil uji statistik didapatkan nilai p>0,05 maka dapat disimpulkan bahwa pada perbandingan antara kedua jenis bahan pemutih gigi yang paling berpengaruh terhadap kekerasan permukaan email gigi setelah aplikasi adalah tidak signifikan .

\section{PEMBAHASAN}

Hasil uji statistik Paired Sampel T-test untuk mengetahui penurunan kekerasan permukaan email gigi pada kelompok I dengan perlakuan berupa aplikasi bahan pemutih gigi karbamid peroksida $10 \%$ didapatkan nilai $\mathrm{p}=0,0001$ dengan $\mathrm{p}<0,05$ dan penurunan kekerasan permukkaan email gigi pada kelompok II dengan perlakuan berupa aplikasi bahan pemutih gigi hidrogen peroksida $6 \%$ didapatkan nilai $p=0,0001$ dengan $p<0,05$, maka dapat disimpulkan bahwa terjadi penurunan kekerasan permukaan email gigi yang sangat signifikan antara sebelum dan setelah aplikasi bahan pemutih gigi karbamid peroksida $10 \%$ dan hidorgen peroksida $6 \%$.

Data yang diperoleh dapat diketahui terjadi penurunan kekerasan permukaan email gigi setelah aplikasi bahan pemutih gigi karbamid peroksida $10 \%$ sebesar 74,50 $\pm 31,14$ VHN. Penurunan rerata nilai kekerasan permukaan email gigi setelah aplikasi bahan pemutih gigi hidrogen peroksida $6 \%$ sebesar $64,37 \pm 45,70$ VHN.

Adanya penurunan kekerasan permukaan email gigi disebabkan karena terjadinya demineralisasi pada email gigi. Demineralisasi email adalah rusaknya hidroksiapatit gigi yang merupakan komponen utama dari email gigi. Demineralisasi terjadi jika $\mathrm{pH}$ disekeliling permukaan email lebih rendah dari 5,5 dan konsentrasi asam di luar permukaan email gigi lebih tinggi daripada di dalam email gigi. ${ }^{13}$

Demineralisasi terjadi melalui proses difusi, yaitu proses perpindahan molekul atau ion yang larut dalam air atau dari dalam email gigi karena adanya perbedaan konsentrasi dari keasaman bahan pemutih gigi di permukaan email gigi dengan di dalam email gigi. Larutan dengan konsentrasi tinggi dan $\mathrm{pH}$ awal yang rendah akan berdifusi ke dalam email gigi melaui kisi kristal dan prisma tubuli yang mengandung air dan matriks organik berupa protein. $\mathrm{pH}$ berperan pada proses demineralisasi karena $\mathrm{pH}$ yang rendah akan meningkatkan konsentrasi ion $\mathrm{H}^{+}$yang akan merusak hidroksiapatit email gigi. Semakin rendah $\mathrm{pH}$ atau semakin asam media maka makin tinggi reaksi pelepasan ion kalsium dari email gigi. ${ }^{13}$

Saat email berkontak dengan bahan pemutih gigi, maka ion hidrogen $\left(\mathrm{H}^{+}\right)$akan menyerang permukaan email gigi sehingga akan terjadi demineralisasi yang menyebabkan larutnya hidroksiapatit pada email gigi yang akan melepaskan ion $\mathrm{Ca}^{2+}, \mathrm{PO}_{4}{ }^{9-}, \mathrm{OH}^{-}$.Ion-ion ini akan berikatan dengan ion hidrogen $\left(\mathrm{H}^{+}\right)$dan ion anion dari asam yang akan membentuk senyawa kompleks yang akan larut dan menyebabkan hilangnya mineral dari permukaan email gigi. ${ }^{14}$ Demineralisasi gigi yang terjadi terus menerus akan menyebabkan porositas pada permukaan email gigi yang mengakibatkan penurunan kekerasan permukaan email gigi dan email gigi menjadi rapuh sehingga rentan terhadap keausan dan karies. ${ }^{13}$

Email sebagian besar terdiri dari hidroksiapatit $\left\{\mathrm{Ca}_{10}\left(\mathrm{PO}_{4}\right)_{6}(\mathrm{OH})_{2}\right\}$ atau Fluoroapatit $\left\{\mathrm{Ca}_{10}\left(\mathrm{PO}_{4}\right)_{6} \mathrm{~F}_{2}\right\}$. Demineralisasi email adalah rusaknya hidroksiapatitgigi akibat proses kimia terjadi bila $\mathrm{pH}$ larutan disekekliling permukaan email lebih rendah dari 5,5. Kecepatan melarutnya email dipengaruhi oleh derajat keasaman $(\mathrm{pH})$, konsentrasi asam, waktu melarut dan kehadiran ion sejenis kalsium. ${ }^{15}$

Teknik home bleaching merupakan prosedur pemutihan gigi populer dan semakin meningkat digunakan masyarakat di rumah. Teknik ini menjadi pilihan karena prosedur penggunaannya yang relatif 
mudah, aman untuk digunakan dan biaya perawatan yang relatif rendah. bahan yang sering digunakan pada teknik ini adalah karbamid peroksida 10-15\% atau hidrogen peroksida 3-6\%. Bahan pemutih gigi karbamid peroksida $10 \%$ merupakan suatu senyawa yang tidak berbau, tidak toksit, berbentuk kristal putih dan merupakan kombinasi antara $7 \%$ urea dan $3 \%$ hidrogen peroksida. ${ }^{6}$ Matis melakukan penelitian pada tahun 2003 dan menyebutkan bahwa bahan pemutih gigi karbamid peroksida $10 \%$ walaupun membutuhkan waktu yang lebih lama dalam reaksi pemutihan dibandingkan dengan bahan pemutih gigi konsentrasi tinggi namun tidak memberikan perubahan irreversible terhadap pulpa. ${ }^{16}$ Hidrogen peroksida $6 \%$ merupakan oksidator kuat yang relatif tidak stabil dan mengalami dekomposisi secara perlahan dan melepaskan oksigen. Hidrogen peroksida mempunyai $\mathrm{pH}$ yang rendah, yaitu $\mathrm{pH} 3 .^{10}$ Pemakaian bahan pemutih gigi dengan konsentrasi tinggi dapat menyebabkan perubahan sel-sel enzim di dalam pulpa yang dapat menyebabkan timbulnya sensitifitas pada pulpa. ${ }^{17}$

Perbandingan yang cenderung signifikan pada pengaruh antara kedua jenis bahan pemutih gigi yang digunakan kemungkinan disebabkan karena nilai konsentrasi dari dua jenis bahan pemutih gigi yang digunakan pada penelitian ini tidak berbeda jauh yaitu $10 \%$ karbamid peroksida setara dengan 3-6\% hidrogen peroksida. $\mathrm{pH}$ juga mempengaruhi hasil perbandingan yang tidak signifikan pada pengaruh antara kedua jenis bahan pemutih gigi yang digunakan karena banyak produk bleaching mempunyai $\mathrm{pH}$ 4-7,5. Makin tinggi konsentrasi peroksida, $\mathrm{pH}$ bahan bleaching lebih bersifat asam. ${ }^{18}$ Tingkat $\mathrm{pH}$ yang rendah dan konsentrasi asam yang tinggi menyebabkan erosi email. ${ }^{19}$

Karbamid peroksida $10 \%$ yang diaplikasikan selama 6 jam menyebabkan gigi kehilangan 1 mikrogram $\mathrm{Ca} / \mathrm{mm}^{2}$ pada email dan diberikan kalsium pada karbamid peroksida untuk meningkatkan kembali kekerasan email. ${ }^{20}$ Penambahan sedikit kalsium pada larutan asam dapat menurunkan kehilangan email sampai $50 \%{ }^{19}$ Penelitian Noerdin pada tahun 2009 menyatakan bahwa pemutihan gigi dengan hidrogen peroksida 38\% menurunkan kekerasan permukaan email gigi sampai $31,3 \%$. Selain itu juga terjadi perubahan morfologi pada email gigi setelah pemutihan yaitu permukaan yang kasar karena adanya porositas dan erosi. ${ }^{1}$ Pada penelitian lain juga dinyatakan bahwa terjadi penurunan kekerasan permukaan email yang signifikan setelah diapliakasi karbamid peroksida $45 \%$ karbamid peroksida dan $38 \%$ hidrogen peroksida. kekerasan permukaan email gigi kembali meningkat setelah diapliasikan fluoride walaupun kekerasannya tidak mencapai kekerasan

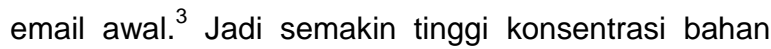
bleaching, semakin rendah $\mathrm{pH}$ dan penurunan microhardness lebih besar dan cepat. ${ }^{7}$

\section{KESIMPULAN}

Terjadi penurunan nilai kekerasan permukaan email gigi yang sangat signifikan pada nilai rata-rata kekerasan permukaan email gigi antara sebelum dan setelah aplikasi bahan pemutih gigi karbamid peroksida $10 \%$ dan aplikasi bahan pemutih gigi hidrogen peroksida $6 \%$.

Pada perbandingan antara kedua jenis bahan pemutih gigi (karbamid peroksida 10\% dan hidrogen peroksida 6\%) yang paling berpengaruh terhadap kekerasan permukaan email gigi setelah aplikasi cenderung signifikan karena konsentrasi dan $\mathrm{pH}$ yang tidak berbeda jauh dari kedua jenis bahan pemutih.

\section{DAFTAR PUSTAKA}

1. Noerdin A, Astrid Y, Yosi KE. Efek bahan remineralisasi terhadap kekerasan email gigi setelah pemutihan dengan hidrogen peroksida $38 \%$ (penelitian in vitro). Jurnal PDGI. 2009;53 (3):110-5.

2. Sukartini, Endang, Firsta Dianty, Milly Armilia. Bleaching internal untuk merawat warna gigi insisivus sentralis kanan atas. Dentofasial Jurnal Kedokteran Gigi. 2011;10(2):101-4.

3. Jurnalis, Devriza, Endang Sukartini, Setiawan Natasasmita. The diffrerences of tooth density changes in the application of $45 \%$ carbamide peroxide pf and 38\% hydrogen peroxide pf as dental bleaching agents and after the application of $1,2 \%$ acidulated phosporic fluoride. Padjajaran Journal of Dentistry. 2010;22(1):24-30.

4. Sugianti, Nanik. Effect of apple juice on whitening teeth after immersion in coffee solution in vitro. Insisiva Dental Jurnal. 2012;1(2):17-9. 
5. Fauziah, Cut, Fitriyani Sri, Viona Diansari. Colour change of enamel after application of averrhoa bilimbi. Jurnal of Dentistry Indonesia. 2012; 19(3):53-6.

6. Hilya, Sundari L, Viona Diansari, Zulfan MA. Perbandinngan efektifitas pemutihan email gigi antara stroberi (fragaria sp) dan apel (malus sp) sebagai bahan bleaching alami dengan karbamid peroksida 10\%. Cakradonya Dental Journal. 2012; $4(2): 494-500$.

7. Suprastiwi, Endang. Penggunaan karbamid peroksida sebagai bahan pemutih gigi. Indonesia Journal of Dentistry. 2005;12(3):139-45.

8. Meizarini, Asti, Mardiana A. Adam. Sitotoksisitas pemutih gigi berdasarkan konsentrasi bahan. Dentofasial Jurnal Kedokteran Gigi. 2010;9(2):11622.

9. Duncan, Linda L. Dental Practice Tool Kit Patient Handouts, Forms, and Letters. Elsevier Inc. 2004: 126-34.

10. Kelleher Martin. Dental bleaching operative dentistry. Quintessentials Publishing. 2008:1-35.

11. Sundoro EH, Margono DA, Kamizar. Pengaruh pemakaian bahan pemutih gigi yang mengandung H2O2 6\% terhadap email. Jurnal Kedokteran Gigi UI.2000;7(1):1-6. Dalam: Alma, Rahmi FA, dkk. Pemutihan Gigi Teknik Home Bleaching dengan Menggunakan Karbamid Peroksida;2007.

12. Anusavice, Kenneth J. Phillips' Science of Dental
Material. Edisi ke-10. Alih bahasa : drg. Johan Arief Budiman dan drg. Susi Purwoko. Jakarta: EGC; 2003.

13. Prasetyo, Edhie Arif. Keasaman minuman ringan menurunkan kekerasan permukaan gigi. Majalah Kedokteran Gigi (Dent J). 2005;38(2):60-3.

14. Lussi A, Jaeggi T. Dental erosion : from diagnosis to therapy. Clin Oral Invest. 2008;12(1):S5-13.

15. Meizarini, Asti, Pambudi SantosoT, Devi Rianti. Kekerasan permukaan email setelah aplikasi gel karbamid peroksida 10\% dan pasta buah strowberry. Dentofasial Jurnal Kedokteran Gigi. 2009;8(2):118-24.

16. Matis, Bruce A. Tray Whitening : what the evidence show. Compendium. 2003;24(4A):1-7.

17. Schulte JR, Morrissette DB, Gasior EJ, Czajewski $M V$. The Effect of bleaching application time on the dental pulp. J Am Dent Assoc. 1994;125(10):13305 .

18. Miranda, C.B., Pagani, C., Benetti, A. R., Matuda, F. Evaluation of the bleached human enamel by scanning electron Microscopy. J. Appl Oral Sci. 2005;13(2):204-11.

19. Price RBT, Sedarous M, Hiltz, GS. The $\mathrm{pH}$ of tooth-whitening products. J. Can Dent Assoc. 2000; 66(8):421-6.

20. Schemehorn BR, Novak ED. Use of a calcium peroxide whitening agent for remineralization and recalcificationn of incipient lesions. J. Clin Dent. 2007;18(4):126-30. 